\title{
ВПЛИВ СІМ'Ї НА ВИНИКНЕННЯ ПСИХОСОМАТИЧНИХ РОЗЛАДІВ У ДІТЕЙ МОЛОДШОГО ШКІЛЬНОГО ВІКУ
}

\author{
Оксана Якимчук \\ кандидат філософських наук, \\ доцент кафедри психосоматики та психологічної реабілітації \\ Національний педагогічний університет імені М.П. Драгоманова \\ 01601, Україна, м. Київ, вул. Пирогова, 9 \\ Yakimchyk1409@gmail.com, https://orcid.org/0000-0002-9729-8389 \\ Тетяна Ханецька \\ кандидат психологічних наук, доцент, \\ доцент кафедри психосоматики та психологічної реабілітації \\ Національний педагогічний університет імені М.П. Драгоманова \\ 01601, Україна, м. Київ, вул. Пирогова, 9 \\ tanyadjan7@gmail.com, https://orcid.org/0000-0001-9767-5116
}

\begin{abstract}
Анотація
У статті наголошується актуальність проблеми зростання психосоматичних розладів у дітей молодшого шкільного віку. Медичні працівники в своїй практичній діяльності постійно стикаються з дітьми, патологія яких «ставить їх у глухий кут» у контексті ії подолання, тому що не супроводжується видимими змінами з боку соматичного статусу, які не проявляються й при поглибленому дослідженні, але, в свою чергу, супроводжуються змінами в психологічному стані дитини. Особливої уваги потребує вивчення впливу сім'ї на виникнення психосоматичних розладів у дітей, оскільки незалежно від матеріального достатку та економічного становища, навіть при сприятливих факторах розвитку дитини, неконструктивні стилі сімейного виховання можуть провокувати виникнення психосоматичних розладів. Психіка дитини молодшого шкільного віку характеризується особливою вразливістю та недостатнім критичним мисленням щодо того, що відбувається навколо неї. Будучи членом родини, дитина вступає у певні відносини з батьками, які можуть здійснювати на неї як позитивний, так і негативний вплив. Необхідною умовою для психічного розвитку молодшого школяра є гармонійні стосунки в сім'ї, а саме з батьками. Батьки забезпечують відчуття безпеки в дитини, сприяють засвоєнню нею способів поведінки та реагування на певні життєві обставини. Отримані результати проведеного емпіричного дослідження дали змогу виявити особливості впливу сім’ї на виникнення психосоматичних розладів у дітей молодшого шкільного віку; з'ясувати рівень знань й уявлення батьків про завдання, зміст і методи виховання дітей; виявити особливості батьківського ставлення до дитини; визначити ступінь задоволеності дітей своїм положенням у сім'ї.
\end{abstract}

Ключові слова: психосоматичні розлади, діти молодшого шкільного віку, сім'я, стилі сімейного виховання, психологічний клімат сім'ї, тривожність, стресові ситуації. 


\section{Вступ}

Однією 3 найбільш актуальних проблем сьогодення $\epsilon$ проблема зростання психосоматичних розладів у дітей, особливо в молодшому шкільному віці. Ця проблема не втрачає своєї актуальності в зв'язку з розширенням кола різноманітних психотравмуючих факторів.

Медичні працівники в своїй практичній діяльності постійно стикаються з дітьми, чия патологія «ставить їх в глухий кут» у контексті іï подолання, оскільки така патологія не супроводжується видимими змінами з боку соматичного статусу, не проявляються й при поглибленому дослідженні. Водночас, ці стани відрізняються швидкістю перебігу й пов'язані 3 наростаючими стражданнями дитини, вибивають іiї із повсякденного життя, а також вони негативно впливають на психологічний статус дитини - аж до соціальної дезадаптації.

Незважаючи на ряд досліджень у медичній та психологічній науках, досі залишаються дискусійними питання, що стосуються сутнісного змісту та ролі факторів різного рівня у виникненні психосоматичних розладів у дітей (Александров, 1993; Бажурин \& Федорова, 2010; Бройтигам, Кристиан \& Рад фон М., 1999; Исаев, 1996; Мозгова, Ханецька \& Якимчук, 2021; Beketova, Mozgova, Shekera, Beketova \& Liubava-Stephania, 2019).

Психосоматичні розлади різноманітні, вони можуть вражати практично будь-які органи й системи. Для розуміння механізму виникнення, для більш ефективної діагностики, лікування та профілактики психосоматичні розлади систематизують за віковою ознакою або передбачуваними патогенетичними механізмами. Зв'язок психосоматичних розладів з віком умовний, оскільки вони можуть проявлятися у будь-якому віці. Виділення психосоматичних розладів, засноване на патогенезі, дозволяє розширити наші уявлення про різноманітність їх клінічних проявів та підвищити ефективність профілактики та психотерапії.

Щодо психологічних факторів, що є передумовою виникнення психосоматичних порушень, то вони досить різноманітні. Зусиллями багатьох авторів була створена багатофакторна відкрита модель, котра пояснює виникнення психосоматичних порушень поєднанням соціальних, психологічних та біологічних впливів яким піддається індивід (Мозгова, Ханецька \& Якимчук, 2021; Петрюк \& Якущенко, 2003). Особливу увагу привертає вплив сім’ї на виникнення психосоматичних розладів у дітей молодшого шкільного віку, оскільки незалежно від матеріального достатку та економічного становища, навіть при сприятливих факторах розвитку дитини, неконструктивні стилі сімейного виховання можуть провокувати виникнення у них психосоматичних розладів (Билецкая, 2010; Еремина, 2015).

У формуванні особистості дитини сім'я відіграє одну із визначальних ролей. Сім'я це мала соціальна група, що базується на кровній спорідненості, члени сім'ї споріднені ще й емоційними зв'язками, моральною відповідальністю та відповідальністю один перед одним, побутом тощо. Для дитини сім'я - це цілий світ, у якому вона живе, діє, робить відкриття, вчиться любити, ненавидіти, радіти, співчувати. Будучи членом родини, дитина вступає у певні відносини з батьками, що можуть здійснювати на неї як позитивний, так і негативний вплив й провокувати тим самим виникнення психосоматичних розладів (Билецкая, 2010; Еремина, 2015; Исаев, 1996; Крейслер, 1994;).

На думку багатьох авторів (Л. Божович, А. Бодальов, В. Мухіна, Т. Рєпіна та ін.), дитина як найчуттєвіша частина соціуму піддається різноманітним негативним впливам. В останні роки, як свідчать спеціальні емпіричні дослідження, найбільш розповсюдженими серед дітей, особливо молодшого шкільного віку, є тривожність і страхи (І. Дубровіна, 
В. Гарбузов, А. Захаров, С. Ковальова та ін.). На жаль, частота психосоматичних порушень в структурі загальної захворюваності в дітей з кожним роком зростає. Такі діти не мають діагностично верифікованих захворювань, хоча й відчувають безліч соматичних скарг. Питома вага таких дітей у різних популяціях має значні варіації в залежності від етнокультуральних особливостей, соціального оточення, стилю виховання (Еремина, 2015; Исаев, 1996; Beketova, Mozgova, Shekera, Beketova \& Liubava-Stephania, 2019).

У сучасному суспільстві простежується криза сім’ї, яка виявляється не тільки в соціально-економічній площині. Часто спостерігається неготовність подружжя до батьківства, відсутність у батьків єдиної стратегії сімейного виховання дітей, його послідовності та нездатність прогнозувати наслідки виховання. Аналіз сучасного суспільства та сім'ї в ньому, проведений вченими, свідчить про те, що сім'я часто нездатна створити умови для соціалізації дитини та гармонійного іiї розвитку. Це призводить до виникнення різноманітних психологічних проблем i, як наслідок, захворювань.

На жаль, на сьогоднішній день психосоматика недостатньо досліджена у психологічній науці, тому рівень і глибина уявлень про психосоматичні порушення, зокрема, у дітей молодшого шкільного віку, залишаються не достатньо вивченими, й відображають лише зовнішні аспекти цього феномена.

Актуальність нашого дослідження визначається також високою соціальною значимістю зазначеної проблеми, швидким темпом ii поширення, а також необхідністю проведення нових фундаментальних досліджень у цій галузі.

Мета дослідження: теоретично виявити та емпірично дослідити особливості впливу сім'ї на виникнення психосоматичних розладів у дітей молодшого шкільного віку. Завдання дослідження: 1) здійснити теоретичний аналіз підходів вітчизняних і зарубіжних вчених щодо чинників виникнення психосоматичних розладів та особливостей впливу сім'ї на їх виникнення у дітей; 2) емпірично дослідити особливості впливу різних стилів сімейного виховання на виникнення психосоматичних розладів у дітей молодшого шкільного віку; 3) виявити ступінь задоволеності дітей своїм положенням у сім’ї.

\section{Методи дослідження}

Для виявлення особливостей впливу стилю сімейного виховання на виникнення психосоматичних розладів у дітей молодшого шкільного віку було використано комплекс методів дослідження: теоретичні (аналіз психологічної літератури; систематизація, узагальнення та структурування даних); емпіричні (клінічне інтерв'ю, тестування, проективні методи):

1. Для діагностики батьків та дітей молодшого шкільного віку на початку дослідження з метою оцінки медико-психологічних особливостей дітей та для відокремлення дітей саме 3 психосоматичними розладами було використано діагностичне інтерв'ю. Також цей метод дозволив виявити психологічні феномени, симптоми та синдроми порушень, внутрішню картину хвороби та структуру проблеми кожної дитини через метод психологічного впливу на дитину, який здійснювався безпосередньо у процесі особистого контакту з дитиною та іiї батьками.

Інтерв'ю було націлене не тільки на скарги, але й на виявлення прихованих мотивів поведінки досліджуваних та на надання психологічної допомоги батькам в усвідомленні внутрішніх психологічних причин хворобливого стану дитини. В інтерв'ю брали участь двоє батьків та сама дитина. 
2. Для діагностики дітей молодшого шкільного віку використовувались наступні методики:

- тест «Кінетичний малюнок сім'ї Р. Бернса $i$ C. Кауфмана», метою якого є діагностика внутрішньородинних відносин. Тест допомагає виявити ставлення дитини до членів своєї родини, те, як вона сприймає кожного з них та свою роль у родині, а також ті взаємовідносини, які викликають у неї тривожні та конфліктні почуття. Ситуація в родині, яку батьки оцінюють позитивно, може сприйматися дитиною цілком протилежно. Дізнавшись, яким вона бачить навколишній світ, родину, батьків, себе, можна зрозуміти причини виникнення багатьох проблем, які є у дитини, та ефективно допомогти їх вирішити;

- методика «Незакінчені речення» Сакса - Леві (модифікація для дітей В. Міхала), використовувалася з метою виявлення рівня ставлення дітей до батьків, а також виявлення причин, що викликають порушення у дітей молодшого шкільного віку;

- методика CMAS (адаптація А. Прихожан). Метою цієї методики є виявлення рівня тривожності у дітей молодшого шкільного віку за шкалою явної тривожності.

3. Для діагностики батьків дітей молодшого шкільного віку були використані:

- методика «Стратегї сімейного виховання» С. Степанова в модифікації I. Махоніної;

- тест-опитувальник батьківського ставлення А. Варга, В. Століна. Мета: виявити рівень батьківського ставлення до дітей молодшого шкільного віку. Батьківське ставлення розуміється як система почуттів і вчинків дорослих людей щодо дітей. Батьківське ставлення - це педагогічна психосоціальна установка щодо дітей, що включає в себе раціональний, емоційний та поведінковий компоненти.

\section{Результати та дискусії}

Психосоматика (греu. psyche - душа, soma - тіло) - напрям у медицині та психології, що займається вивченням впливу психологічних (переважно психогенних) факторів на виникнення і подальшу динаміку соматичних захворювань. Згідно основного постулату цієї науки, в основі психосоматичного порушення лежить реакція на емоційне переживання, що супроводжується функціональними змінами і патологічними порушеннями в органах (Мозгова, Ханецька \& Якимчук, 2021).

Будь-який психосоматичний розлад є властивістю людського організму як системи. Він не походить окремо ні з психічних, ні з фізіологічних якостей індивіда, його неможливо пояснити шляхом дослідження властивостей якоїсь однієї підсистеми - психічної чи соматичної. Лише взаємодія між цими підсистемами та оточуюче середовище можуть призвести до нового стану організму, який визначається як психосоматичний розлад. I лише розуміння цих зв’язків може дати можливість ефективно впливати на порушення, що виникло, в тому числі й засобами психокорекції та психотерапії (Сандомирский, 2007; Старшенбаум, 2014).

Внутрішні конфлікти, невротичні типи реакцій або психореактивні зв'язки зумовлюють картину органічного страждання, його довготривалість, особливості протікання, i, можливо, резистентність до терапії. Психосоматичні порушення в дитячому віці впливають на розвиток особистості, а психічні стани впливають на соматичний стан.

Причиною психосоматичних розладів, як свідчить аналіз вітчизняних та зарубіжних літературних джерел, є порушення адаптації дитини внаслідок тривоги та стресу, в якому вона перебуває. В своїх роботах Г. Сельє стверджував, що навіть «спляча людина відчуває 
стрес, а повна свобода від стресу означає смерть» (Сельє, 1992: 104). Вплив різних факторів може бути настільки потужним, що організм не може впоратися зі стресом, викликаючи хворобливий стан.

На думку Ф. Александера, взаємодія трьох факторів - психологічних, фізіологічних та соціальних, є передумовою виникнення психосоматичних розладів. В якості психологічних факторів виступають особистісні особливості дитини, негативні емоції, страх та тривога, внутрішні конфлікти. До фізіологічних факторів відносять конституціональну неповноцінність тих або інших органів. До соціальних відносять несприятливий вплив середовища (Александер, 2006).

Ф. Данбар, творець першої теорії специфічності особистісних рис в психосоматиці, вивчаючи особистісні особливості клієнтів 3 різними формами соматичної патології зазначала їх велику схожість при певних захворюваннях, що відрізняє клієнтів даної групи від клієнтів з іншими нозологіями й від людей, які не мають будь яких соматичних порушень (Данбар, 1935; Данбар, 1943). Грунтуючись на даних багаторічних досліджень (понад 1600 спостережень), Ф. Данбар виділила і описала риси, що притаманні для восьми захворювань, які, за даними її досліджень, в більшій мірі, ніж всі інші, залежать від психологічних причин: ревматоїдний артрит та ревматична лихоманка, ревматичні пороки серця, цукровий діабет, артеріальна гіпертензія (АГ), порушення ритму серця, травматизм, бронхіальна астма. Для кожного типу особистості, стверджувала вона, характерні цілком певні способи емоційного переживання та контролю емоцій. Комплекси психологічних характеристик, властиві особистостям певного складу, мають, по Ф. Данбар, і діагностичну, і прогностичну цінність (Данбар, 1935).

Період життя дітей від 6-7 до 11 років називають молодшим шкільним віком. Психіка дітей цього віку характеризується вразливістю, дітям часто властиві боязкість, сором'язливість, вони володіють ще недостатнім критичним мисленням для того, щоб аналізувати те, що відбувається навколо них. Необхідною умовою для гармонійного розвитку молодшого школяра є гармонійні стосунки в сім'єю, а саме з батьками. Батьки забезпечують відчуття безпеки у дитини, сприяють засвоєнню способів поведінки та реагування на певні життєві обставини. Батьки також є основним джерелом знань. Той обсяг знань, який отримує дитина в процесі свого розвитку, залежить від включеності батьків та від ставлення їх до своєї дитини. Діти з великим життєвим досвідом, які вміють знаходити вихід з різних стресових ситуацій, які не мають заборони на прояв емоцій, які вирішують проблеми спілкування, будуть швидко адаптуватися до мінливих умов і позитивно реагувати на зміни. Саме тому більшість вітчизняних та зарубіжних дослідників вважають, що на становлення та розвиток особистості дитини, зокрема, в молодшому шкільному віці впливає саме сім'я та внутрішньо сімейні відносини. Порушені ж дитячо-батьківські стосунки мають визначальний вплив на виникнення та формування психосоматичних розладів у дітей саме цього вікового періоду.

Є. Ейдеміллер, I. Добрякова. та I. Микільська зазначали, що сім’я - це основний засіб розвитку дитини, тому формування психологічних захистів і особливостей особистості дитини залежить від ступеня прихильності батьків до дитини, від психологічного клімату сім'ї, від засвоєння дітьми батьківського стилю поведінки (Эйдемиллер, Добряков \& Никольская, 2003).

Л. Шнейдер вказувала, що існує певна специфіка сімейного виховання, воно засноване на почуттях; сім'я - це різновікова соціальна група; в сім’ї дитина виконує всі 
основні види діяльності: трудову, ігрову, пізнавальну, громадську, ціннісноорієнтовану, художньо-творчу, вільного спілкування; сімейне виховання впливає на весь життєвий цикл людини, незалежно від часу доби і пори року. Поширеними негативними факторами сімейного виховання $\epsilon$ такі: погане матеріальне забезпечення сім’ї, аморальність, переважання прагнення до матеріального благополуччя над духовними потребами; безкарність і всепрощення; відсутність сприятливого психологічного клімату в сім'ї; психолого-педагогічна безграмотність батьків тощо (Шнейдер, 2000: 24-25).

Перша соціалізація з моменту народження у людини відбувається в сім'ї, а порушення сімейних взаємин може спричинити виникнення та формування психосоматичних порушень. Може спостерігатись також такий феномен як «психосоматична сім'я». Для психосоматичної сім'ї, наприклад, нехарактерно заохочення вільного вираження переживань, внаслідок чого дитина привласнює стереотипи придушення емоцій, що поступово призводить до їх соматизації.

Науковці виділяють п’ять характеристик психосоматогенних сімей: 1) надмірна включеність батьків у життєві проблеми дитини, яка заважає розвитку самостійності, отже, послаблює захисні механізми, що сприяє розвитку внутрішнього конфлікту; 2) надчутливість кожного члена сім’ї до дистресу іншого; 3) ригідність взаємин у сім’ї, низька здатність змінювати правила взаємодії при мінливих обставинах; 4) тенденція уникати вираження незгоди й відкритого обговорення конфліктів, що підсилює ризик виникнення внутрішніх конфліктів; 5) дитина 3 його захворюванням часто грає роль стабілізатора в прихованому подружньому конфлікті (Еремина, 2015; Шнейдер, 2000; Эйдемиллер \& Юстицкис, 2008).

Значущим чинником, що впливає на перебіг психосоматичних порушень, є ставлення батьків не тільки до дитини, а й до ії порушення. Ставлення до хвороби дитини позначається й на ставленні до ії особистості (Билецкая, 2010; Крейслер, 1994; Эйдемиллер, Добряков \& Никольская, 2003).

До психосоціальних факторів належать патологічні стилі виховання. Стиль сімейного виховання - це сукупність батьківських стереотипів, що впливають на дитину. Спостереження за дитячо-батьківськими стосунками в різних сім'ях дозволили психологам скласти опис стилів виховання, які виникають під впливом об'єктивних і суб'єктивних факторів і особливостей дитини. На вибір того чи іншого стилю сімейного виховання впливають, в першу чергу, традиції, в яких виховувалися самі батьки. Важливе значення мають індивідуально-особистісні особливості батьків, їх педагогічна культура та психологічна грамотність.

Типи сімейних взаємин, що визначають стиль сімейного виховання, у вітчизняній літературі розглядалися в роботах О. Петровського, Л. Сагатовського, Д. Ісаєва, В. Гарбузова, А. Лічко, Є. Ейдеміллера, В. Мініярова та інших вчених. Запропонована А. Лічко та Є. Ейдеміллер класифікація, побудована на співвідношенні особливостей формування особистості дітей та стилів сімейного виховання, є, на нашу думку, найбільш цікавою з точки зору їі практичного застосування. У стилях сімейного виховання авторами були виділені п'ять відхилень:

1. Гіпопротекиія - характеризується недоліком опіки й контролю, дитина часто залишається без нагляду, ій приділяється мало уваги, відчувається фізична занедбаність, немає інтересу до іiі життя з боку батьків. Виховання носить формальний характер, тому невключенность дитини в життя сім'ї призводить до асоціальної поведінки через незадоволення потреби в любові та прихильності. 
2. Домінуюча гіпопротекція проявляється в заборонах, у підвищеній увазі до дитини, в надмірній опіці та контролі над їі поведінкою, в обмеженні дитини в діях, що згодом призводить або до реакції емансипації, або до формування таких якостей як безініціативність, несамостійність, безвідповідальність, невміння постояти за себе.

3. Потуральну гіпопротекцію називають «вихованням кумира сім’і». Батьки намагаються звільнити своє дитя від найменших труднощів, обожнюють й надмірно опікають, потурають будь-яким його бажанням, захоплюються його мінімальними успіхами й вимагають такого ж захоплення від інших. У дитини формується високий рівень домагань, прагнення до лідерства. А. Маслоу зазначав, що такий стиль формує патологічну потребу в любові й визнанні. Особистість, яка виховується в такій сім'ї, нерідко відчуває в житті негативні переживання, оскільки «сліпа» батьківська любов не навчила дитину справлятися 3 труднощами й неприємностями.

4. При стилі «емочійне відкидання» батьки обтяжені своєю дитиною, іiї потреби ігноруються, 3 нею жорстоко поводяться, дитина-тягар часто зустрічає приховане емоційне відкидання. Цей стиль сімейного виховання надає найбільш негативний вплив на розвиток особистості дитини. 3. Фройд писав, що в таких сім'ях можуть бути присутніми всі чотири «тривожні» ситуації: втрата бажаного об'єкта, втрата любові, втрата особистості, втрата любові до себе.

5. Стиль сімейного виховання «підвищена моральна відповідальність» виражається у вимозі від дитини надмірної чесності, порядності, розвитку почуттів, що не відповідають ії віку. Іноді підлітку насильно приписують роль «голови сім'ї», передоручають догляд за молодшими братами та сестрами або за престарілими. Батьки пророкують особливе майбутнє своєї дитини, а дитина боїться їх розчарувати, щиро намагаючись виправдати їх надії (Исаев, 1996; Минияров, 2006; Эйдемиллер, Добряков \& Никольская, 2003).

Можна ще доповнити список відхилень в стилі батьківського виховання: перевага жіночих, чоловічих або дитячих якостей, розширення сфери батьківських почуттів, страх втрати дитини, нерозвиненість батьківських почуттів, проекція власних небажаних якостей, перенос конфлікту між подружжям у сферу виховання. Із цього випливає, що батьківський стиль - це узагальнені, характерні, ситуаційно неспецифічні способи спілкування батьків 3 дитиною, це образ дій по відношенню до дитини. Отже, можна припустити, що ті чи інші відхилення у сімейних взаєминах можуть виступати факторами ризику виникнення певних психосоматичних порушень у дітей на мікросоціальному рівні. Якщо ж говорити про фактори ризику порушення психосоматичного здоров'я дітей на макросоціальному рівні, то домінуючими 3 них є девіантні форми батьківства, соціальна нерівність та недосконала система освіти.

В структуру девіантних форм батьківства слід включити такі чинники ризику психосоматичних розладів як соціальне сирітство, алкоголізація батьків, різні форми сімейного насильства й тотальну зайнятість сучасних батьків, що не дозволяє їм адекватно реалізовувати свої батьківські функції.

Дискусійним залишається питання про роль соціальної нерівності у виникненні психосоматичних розладів у дітей молодшого шкільного віку. Деякими дослідниками відзначається, що частота появи психосоматичних порушень серед дітей з сімей 3 низьким соціальноекономічних статусом набагато вище, ніж серед дітей із сімей 3 середнім та високим рівнем доходу (Эйдемиллер, Добряков \& Никольская, 2003). Крім того, відомо, що діти, які часто турбуються про фінансовий статус своєї сім’ї, часто демонструють такі 
психосоматичні скарги як головний біль, біль у животі та кардіалгії, проте масштабних досліджень такого рівня не проводилося.

До емпіричного дослідження також було залучено учнів декількох загальноосвітніх шкіл міста Києва віком 7-8 років. За допомогою діагностичного інтерв'ю для подальшого дослідження було обрано 30 учнів. Батьки цих дітей неодноразово зверталися до сімейного лікаря з приводу паганого самопочуття дітей, розладів у роботі їх органів та систем, про що свідчать відповідні записи в медичній карті амбулаторного хворого. Проте, при обстеженні будь-яких порушень в роботі органів або систем дітей виявлено не було, навіть при клінічному дослідженні, що дозволяє нам зробити попередній висновок, що діти мають певні психосоматичні розлади.

Згідно даних, отриманих під час діагностичного інтерв’ю, було виявлено, що переважна більшість розладів (48\%) відноситься до проблем у роботі шлунково-кишкового тракту (болі в животі, нудота та психогенне блювання, запори, проноси, порушення апетиту (як збільшення, так і зниження); порушення терморегуляції (схильність до безпричинних коливань субфибрильної температури) спостерігалось у 9\% досліджуваних дітей; часті респіраторні захворювання, що перебігають ланцюгово зі зміною одного незавершеного епізоду іншим, а, іноді, із нашаруванням симптомів у 22\% досліджуваних; алергічні реакції у $8 \%$ дітей; порушення в роботі органів дихання - у 13\%. Відокремлення виду та типу розладу є дуже важливим, оскільки це може вказувати на його етіологію.

Було також виявлено, що у 76\% дітей психосоматичні розлади почали з'являтися після стресу або негативних емоційних переживань; у 24\% досліджуванихї порушення соматичного стану відзначалося 3 перших місяців життя; у 90\% дітей спостерігалося погіршення соматичного стану після емоційного напруження, стресу, тривоги, конфліктів у школі або вдома.

За результатами методики «Кінетичний малюнок сім'ї» було виявлено, що в 30\% дітей у сім'ях переважає сприятлива ситуація, нормальна психологічна атмосфера. На малюнках цих дітей були присутні всі члени сім'ї. У центрі малюнка дитина зображувала себе в оточенні своїх батьків, усі члени родини зображені з досить ретельно промальованими деталями. На обличчях дорослих і дитини були присутні посмішки, зображення поз та рухів членів родини характеризували сприятливу атмосферу в сім'ї. Проте, в 70\% сімей були наявні певні проблеми та труднощі у взаєминах між батьками та їх дітьми, що, безумовно, негативно впливає на особистісний розвиток дитини. До цієї групи були віднесені малюнки дітей, у яких був відсутній хтось із членів сім’і, дитина малювала себе сумною, зображувала себе далеко від батьків. Діти ретельно штрихували деталі, іноді були відсутні деякі частини тіла у членів родини - це характеризувало занепокоєння та ворожість дитини у ставленні до дорослих. Декілька сімей мали низький рівень батьківських стосунків. На малюнках дітей цієї групи зображено заляканий вираз обличчя дитини, емоційна напруга дитини виражалася через використання нею у малюнку темних фарб. Розведені руки та розчепірені пальці у членів сім’ї говорять про наявність у дітей ворожості до батьків.

Як виявилося в процесі емпіричного дослідження, дуже поширеною особливістю малюнків було зображення неповного складу сім’і. Часто діти молодшого шкільного віку не зображували себе або, навпаки, малювали лише себе. Такі малюнки свідчать про емоційне відчуження, конфліктність у родині. Дитина, яка відмовляється або «забуває» намалювати себе, ймовірно, почувається винною у несприятливій сімейній ситуації. Дитина, яка малює лише себе, схильна до засвоєння стратегії «загубленої дитини». Найчастіше діти не 
малювали узалежненого члена родини, а це означає, що дитина звинувачує в сімейних проблемах саме його, виражає агресію до нього.

Аналіз результатів інтерпретації симптомокомплексів показав що сприятлива сімейна ситуація притаманна $30 \%$ сімей, конфліктність виявлена у $24 \%$ діагностованих випадків, тривожність - у 26\%, почуття неповноцінності - у 10\%, ворожість притаманна $10 \%$ досліджуваних сімей.

Дослідження за методикою «Незакінчених речень Сакса - Леві, модифікація Міхала» дозволило виявити відносини дітей до батька, матері, сім’ї, а також відношення до хвороби.

Ставлення до батька у досліджуваних неоднозначне: 60\% досліджуваних дітей вважають, що батько приділяє їм мало уваги, що він не повністю реалізував свої мрії, не переймається домашніми турботами та мало приділяє зусиль для облаштування власного життя. Провідною темою відповідей дітей є незадоволеність матеріальним статком сім'ї, причому в цій проблемі звинувачують також батька 25\% досліджуваних, 40\% досліджуваних ставляться з розумінням до батька та відчувають його підтримку.

Аналізуючи результати ставлення до матері, ми можемо прийти до висновку, що воно більш позитивне. Переважна більшість, а, саме, 70\% досліджуванних, вказали на те, що вони в дружніх стосунках з матір'ю й повністю їй довіряють, 10\% досліджуваних вказали на те, що вона є їх авторитетом. Крім того, були й такі діти (30\%), які відчувавали погане ставлення до себе й невідповідальність зі сторони матері, відчували образу на неї, тобто у них спостерігалося негативне ставлення до матері.

Ставлення до сім'ї в досліджуваних дітей переважно позитивне, не дивлячись на те, що більшість 3 них ставиться негативно до батька (60\%) та до матері (30\%). Вони вважають, ix сім'я найкраща, щаслива й живе у достатку. Й лише $25 \%$ досліджуваних дітей до сім’і ставляться негативно.

Ставлення до хвороби. Переважна більшість дітей, а, саме 68\%, вважають, що хвороба має позитивну сторону й лише $32 \%$ досліджуваних вважають, що хвороба не приносить позитиву, а лише неприємн відчуття та обмеження.

Отже, можна зробити висновок: у досліджуваної групи дітей проявляються позитивне ставлення до сім'ї та до матері. Батько не має для них високого авторитету й ставлення до нього носить відтінок негативізму, проте, це не заважає дітям оцінювати свою сім'ю як щасливу та доброзичливу. У досліджуваних дітей виявлений досить великий відсоток позитивного ставлення до хвороби. Хвороба для багатьох дітей - це можливість отримати увагу, уникнути конфлікту або просто бути поміченим й отримати таку бажану увагу зі сторони дорослих.

Результати дослідження за допомогою методики CMAS (адаптаџія А. Прихожан) допомогли нам виявити рівень тривожності в дітей молодшого шкільного віку, яка часто $€$ причиною психосоматичних розладів.

Нормальний рівень тривожності спостерігається у 33\% дітей. Виявлений рівень тривожності необхідний для адаптації й продуктивної діяльності дитини. Трохи підвищена тривожність була виявлена у 53\% дітей. Явно підвищений рівень тривожності притаманний $14 \%$ дітей.

У ході дослідження за допомогою методики «Стратегії сімейного виховання» C. Степанова в модифікаиії I. Махоніної нами були отримані наступні результати: авторитарний стиль виховання притаманний $50 \%$ сімей; ліберальний - $18 \%$ сімей; демократичний (авторитетний) - $17 \%$ сімей; індиферентний - $15 \%$ сімей. 
Зазначені дані підтверджують співпадіння 3 відсотком тривожності у дітей, їх ставленням до батьків, проявом у них психосоматичних порушень та іх інтенсивністю.

3 метою виявлення рівня батьківського ставлення до дітей молодшого шкільного віку було застосовано тест-опитувальник батьківського ставлення А. Варга, В. Століна. Результати дослідження зазначені в табл. 1.

Таблиия 1

Батьківське ставлення до дітей молодшого шкільного віку

\begin{tabular}{|c|c|c|c|c|c|c|c|c|c|c|}
\hline \multirow{2}{*}{ 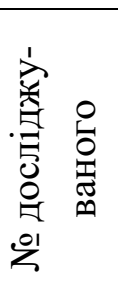 } & \multicolumn{2}{|c|}{$\begin{array}{c}\text { Прийняття- } \\
\text { Відторгнення }\end{array}$} & \multicolumn{2}{|c|}{ Кооперація } & \multicolumn{2}{|c|}{ Симбіоз } & \multicolumn{2}{|c|}{$\begin{array}{c}\text { «Автори- } \\
\text { тарна } \\
\text { гіперсо- } \\
\text { ціалізація» }\end{array}$} & \multicolumn{2}{|c|}{$\begin{array}{c}\text { «Маленький } \\
\text { невдаха» }\end{array}$} \\
\hline & $\mathrm{c} / 6$ & $\Pi / \mathrm{p}$ & $\mathrm{c} / 6$ & $\Pi / \mathrm{p}$ & $\mathrm{c} / 6$ & $\Pi / \mathrm{p}$ & $\mathrm{c} / \sigma$ & $\Pi / \mathrm{p}$ & $\mathrm{c} / \sigma$ & $\Pi / \mathrm{p}$ \\
\hline 1. & 5 & 0 & 7 & 31,19 & 5 & 86,63 & 6 & 95,76 & 2 & 70,25 \\
\hline 2. & 6 & 0,63 & 7 & 31,19 & 5 & 86,63 & 5 & 83,79 & 5 & 96,83 \\
\hline 3. & 4 & 0 & 8 & 48,82 & 4 & 74,97 & 6 & 95,76 & 3 & 84,81 \\
\hline 4. & 3 & 0 & 7 & 31,19 & 4 & 74,97 & 6 & 95,76 & 3 & 84,81 \\
\hline 5. & 7 & 3,79 & 7 & 31,19 & 4 & 74,97 & 4 & 69,30 & 2 & 70,25 \\
\hline 6. & 2 & 0 & 8 & 48,82 & 4 & 74,97 & 5 & 83,79 & 2 & 7,25 \\
\hline 7. & 4 & 0 & 8 & 48,82 & 5 & 86,63 & 6 & 95,76 & 3 & 84,81 \\
\hline 8. & 3 & 0 & 9 & 80,33 & 4 & 74,97 & 5 & 83,79 & 3 & 84,81 \\
\hline 9. & 5 & 0 & 7 & 31,19 & 5 & 86,63 & 5 & 83,79 & 2 & 70,25 \\
\hline 10. & 3 & 0 & 9 & 80,33 & 4 & 74,97 & 5 & 83,79 & 3 & 84,81 \\
\hline 11. & 6 & 0,63 & 9 & 80,33 & 4 & 74,97 & 6 & 95,76 & 4 & 93,04 \\
\hline 12. & 4 & 0 & 8 & 48,82 & 4 & 74,97 & 5 & 83,79 & 3 & 84,81 \\
\hline 13. & 8 & 12,02 & 8 & 48,82 & 5 & 86,63 & 5 & 83,79 & 3 & 84,81 \\
\hline 14. & 2 & 0 & 9 & 80,33 & 5 & 86,63 & 6 & 95,76 & 2 & 70,25 \\
\hline 15. & 7 & 3,79 & 8 & 48,82 & 5 & 86,63 & 5 & 83,79 & 3 & 84,81 \\
\hline 16. & 6 & 0,63 & 7 & 31,19 & 4 & 74,97 & 3 & 53,87 & 3 & 84,81 \\
\hline 17. & 3 & 0 & 8 & 48,82 & 5 & 86,63 & 6 & 95,76 & 2 & 70,25 \\
\hline 18. & 8 & 12,02 & 9 & 80,33 & 5 & 86,63 & 5 & 83,79 & 3 & 84,81 \\
\hline 19. & 5 & 0 & 8 & 48,82 & 4 & 74,97 & 6 & 95,76 & 3 & 84,81 \\
\hline 20. & 2 & 0 & 9 & 80,33 & 4 & 74,97 & 5 & 83,79 & 2 & 70,25 \\
\hline 21. & 8 & 12,02 & 8 & 48,82 & 5 & 86,63 & 6 & 95,76 & 4 & 93,04 \\
\hline 22. & 3 & 0 & 8 & 48,82 & 4 & 74,97 & 6 & 95,76 & 3 & 84,81 \\
\hline 23. & 6 & 0,63 & 8 & 48,82 & 5 & 86,63 & 6 & 95,76 & 3 & 84,81 \\
\hline 24. & 2 & 0 & 7 & 31,19 & 4 & 74,97 & 5 & 83,79 & 2 & 70,25 \\
\hline 25. & 4 & 0 & 7 & 31,19 & 4 & 74,97 & 5 & 83,79 & 3 & 84,81 \\
\hline 26. & 6 & 0,63 & 8 & 48,82 & 5 & 86,63 & 6 & 95,76 & 3 & 84,81 \\
\hline 27. & 4 & 0 & 9 & 80,33 & 5 & 86,63 & 5 & 83,79 & 3 & 84,81 \\
\hline 28. & 3 & 0 & 7 & 31,19 & 5 & 86,63 & 4 & 69,30 & 5 & 96,83 \\
\hline 29. & 8 & 12,02 & 8 & 48,82 & 4 & 74,97 & 6 & 95,76 & 2 & 70,25 \\
\hline 30. & 8 & 12,02 & 9 & 80,33 & 4 & 74,97 & 6 & 95,76 & 3 & 84,81 \\
\hline
\end{tabular}


Отримані дані вказують на те, що середні значення за показниками «кооперація» та «авторитарна гіперсоціалізація» характеризуються високим рівнем. Середні значення показника «симбіоз» знаходяться у нормі, показник «маленький невдаха» нижче середнього, a «прийняття-відторгнення» має низький рівень показника. Виходячи 3 отриманих результатів, можна зробити висновок, що батьківське ставлення до дітей грунтується на приймаюче-авторитарному типі батьківського виховання, де прийняття дитини супроводжується 3 вимогами до соціальних успіхів і досягнень. Ці показники вказують також на змішаний тип батьківського ставлення й на те, що батьки занадто сконцентровані на контролі поведінки дитини, вимагаючи від неї надмірної слухняності, тим самим пригнічуючи іiї свободу та самостійність.

Можна зазначити, що демократичному стилю виховання відповідають високі бали за шкалами: «прийняття - неприйняття»; «кооперація»; невисокі бали - за шкалами «симбіоз»; «контроль»; «відношення до невдач дитини».

Авторитарному стилю виховання відповідали невисокі бали по шкалам: «прийняття неприйняття»; «кооперація», «симбіоз», високі бали по шкалам; «контроль»; «відношення до невдач дитини».

Ліберальному стилю виховання відповідають невисокі бали за шкалами: «прийняття неприйняття»; «кооперація»; «відношення до невдач дитини»; високі бали - за шкалам: «симбіоз» та «контроль».

Потуральному стилю виховання відповідають високі бали за шкалами: «прийняття неприйняття»; «кооперація»; «симбіоз»; невисокі бали - за шкалами: «контроль» та «відношення до невдач дитини».

Зіставлення результатів батьківського ставлення та кількості психосоматичних порушень у дітей молодшого шкільного віку дало змогу виявити, що високому рівню психосоматичних розладів відповідає авторитарний стиль сімейного виховання (63\% випадків). На другому місці - потуральний (36\% випадків), на третьому - ліберальний стиль (14\% випадків).

Низькому рівню виникнення психосоматичних розладів відповідає демократичний стиль сімейного виховання (46\% випадків). На другому місці - ліберальний (36\% випадків), на третьому - потуральний стиль (32\% випадків).

\section{Висновки}

Аналіз психологічної літератури вітчизняних і зарубіжних дослідників свідчить: психосоматичні розлади, зазвичай, визначаються як такі, при яких психологічні фактори вважаються основними в розвитку або збереженні соматичного розладу.

Етіологію психосоматичних розладів слід розглядати 3 позиції загальної психосоматичної парадигми. Важливим є те, що один і той самий чинник викликає в різних людей різні реакції та розлади, але, не зважаючи на те, що всі вони різні, в них є цілий ряд спільних ознак, які допомагають діагностувати їх.

Період життя дітей від 6-7 до 11 років називають молодшим шкільним віком. Психіка дітей молодшого шкільного віку характеризується вразливістю, їм властиві надмірна сором'язливість, недостатній рівень критичного мислення для того, щоб аналізувати те, що відбувається навколо них.

Узагальнюючи результати дослідження, можна стверджувати, що найчастіше причини психологічних труднощів у дітей молодшого шкільного віку виходять 3 сім’ї, вони зумовлені 
нервово-психічним станом батьків, їх ставленням до дітей та до життя взагалі. В генезі психосоматичних розладів одним 3 провідних факторів виступає стиль сімейного виховання й загальний фон сімейних взаємин. Це, в основному, походить від того, що батьки недостатньо знають психологічні особливості своєї дитини, у них відсутня єдина стратегія послідовності виховання дітей, вони нездатні прогнозувати наслідки власного виховання, у них відсутня емоційна близькість з дитиною. Позначаються також тип сім’ї, позиція, яку займають дорослі по відношенню до дитини, стилі відносин та роль, що вони відводять дитині в сім'ї. Під впливом певного типу батьківського ставлення формується особистість дитини, іiі психологічний та соматичний стан.

Важливим $є$ й ставлення самої дитини до свого порушення, оскільки це вносить певні корективи у взаємостосунки з родиною через відстороненість, байдужість, надмірні вимоги, відсутність інтересу до дитини або гіперопіку зі сторони батьків. Все це може формувати розлад, який буде виконувати певну функцію, яка буде задовольняти неусвідомлені потреби дитини або родини.

Отже, наведені результати емпіричного дослідження свідчать, що порушення, які були виявлені в дітей молодшого шкільного віку, дійсно психосоматичні, в етіології та патогенезі психосоматичних розладів сім'я відіграє важливе значення тобто психосоматичні розлади дітей мають психогенну природу.

3 огляду на вищезазначене, перспективою подальших досліджень ми вбачаємо в розробці та апробації комплексної програми психокорекції дитячо-батьківських стосунків та профілактики виникнення психосоматичних розладів у дітей молодшого шкільного віку.

\section{Література}

1. Александер, Ф. (2006). Психосоматическая медищина. Принщипь и применение. Москва : Институт Общегуманитарных Исследований.

2. Александров, Ю.А. (1993). Пограничные психические расстройства: руководство для врачей. Москва : Медицина.

3. Антропов, Ю.Ф. (2001). Психосоматические расстройства: курс лекций. Москва : Изд-во Института Психотерапии.

4. Бажурин, В.Б., Федорова, Г.М., \& др. (2010). Основы психосоматики. Донецк : Институт Культуры ДонНТУ.

5. Билецкая, М.П. (2010). Семейная психотерапия детей с психосоматическими расстройствами (ЖКТ). Санкт-Петербург : Речь.

6. Бройтигам, В., Кристиан, П., \& Рад, фон М. (1999). Психосоматическая медицина. Москва : Гэотар Медицина.

7. Варга, А.Я., \& Драбкина, Т.С. (2001). Системная семейная психотерапия: кратк. лекционный курс. Санкт-Петербург : Речь.

8. Еремина, Н.Ю. (2015). Психосоматические расстройства у детей в семьях с различными стилями семейного воспитания. Поволжский педагогический вестник, 4(9), 121-126. Режим доступа: https://cyberleninka.ru/article/n/psihosomaticheskie-rasstroystva-u-detey-vsemyah-s-razlichnymi-stilyami-semeynogo-vospitaniya

9. Исаев, Д.Н. (1996). Психосоматическая медицина детского возраста. Санкт-Петербург : Речь.

10. Крейслер, Л. (1994). Психосоматика в психопатологии младенчества. Мать, дитя, клиницист: Сборник, 112-145. 
11. Минияров, В.М. (2006). Педагогическая психология. Часть І. Психология воспитания Самара : Сам ГПУ.

12. Мозгова, Г.П., Ханецька, Т.I., \& Якимчук, О.І. (2021). Психосоматика: психічне, тілесне, сочіальне. Хрестоматія: Навчальний посібник. Київ : НПУ імені М.П.Драгоманова.

13. Петрюк, П.Т., \& Якущенко, И.А. (2003). Психосоматические расстройства: вопросы дефиниции и классификации. Вестник Ассоциащии психиатров Украиньл, 3-4, 133-140. Режим доступа: http://www.psychiatry.org.ua/articles/paper144.htm

14. Сандомирский, М.Е. (2007). Психосоматика и телесная психотерапия: практ. руководство. Москва : Класс.

15. Селье, Г. (1992). Когда стресс не приносит горя. Москва : МНПП "РЭНАР"

16. Старшенбаум, Г.В. (2014). Психосоматика : руководство по диагностике и самопомощи. Ростов-на-Дону : Феникс.

17. Шнейдер, Л.Б. (2000). Психология семейных отношений. Курс лекиий. Москва : АпрельПресс; ЭКСМО-Пресс. Режим доступа: http://psychlib.ru/mgppu/SPs/SPs-001.HTM

18. Эйдемиллер, Э.Г., Добряков, И.В., \& Никольская, И.М. (2003). Семейный диагноз и семейная психотерапия. Санкт-Петербург : Речь.

19. Эйдемиллер, Э.Г., \& Юстицкис, В.В. (2008). Психология и психотерапия семьи. СанктПетербург : Питер.

20. Beketova, G., Mozgova, G., Shekera, O., Beketova, N., \& Liubava-Stephania (2019). Neurophysiological characteriscs of psychosomatic disorders and psychosomatic pathology in children and adolescents. Wiadomości Lekarskie is abstracted and indexed, tom LXXII, 12 (I), 2282-2288. https://wiadlek.pl/wp-content/uploads/2020/02/WL-12-cz-I-2019.pdf

21. Dunbar, F. (1935). Emotions and bodily changes. American Journal of Psychiatry, 93(3), 749.

22. Dunbar, F. (1943). Psychosomatic diagnosis. New York-London : PB Hoeber.

\section{References}

1. Aleksander, F. (2006). Psihosomaticheskaya medicina. Principy i primenenie [Psychosomatic medicine. Principles and Applications.]. Moscow: Institut Obshhegumanitarnyh Issledovanij [in Russian].

2. Aleksandrov, Yu.A. (1993). Pohranychnye psykhycheskye rasstroistva: rukovodstvo dlia vrachei [Borderline Mental Disorders: A Guide for Physicians]. Moscow : Medytsyna [in Russian].

3. Antropov, Yu.F. (2001). Psykhosomatycheskye rasstroistva: kurs lektsyi. [Psychosomatic disorders: a course of lectures.]. Moscow : Yzd-vo Ynstytuta Psykhoterapyy [in Russian].

4. Bazhurin, V.B., Fedorova, G.M., \& dr. (2010). Osnovy psihosomatiki [Basics of psychosomatics]. Doneck : Institut Kul'tury DonNTU [in Ukrainian].

5. Bileckaya, M.P. (2010). Semejnaya psihoterapiya detej s psihosomaticheskimi rasstrojstvami (ZHKT) [Family psychotherapy for children with psychosomatic disorders (GIT)]. Saint Petersburg : Rech' [in Russian].

6. Brojtigam, V., Kristian, P., \& Rad, fon M. (1999). Psihosomaticheskaya medicina [Psychosomatic medicine]. Moscow : Geotar Medicina [in Russian].

7. Varga, A.Ya., \& Drabkina, T.S. (2001). Sistemnaya semejnaya psihoterapiya: kratk. lekcionnyj kurs [Systemic family psychotherapy: brief. lecture course]. Saint Petersburg : Rech' [in Russian]. 
8. Eremina, N.YU. (2015). Psihosomaticheskie rasstrojstva u detej v sem'yah s razlichnymi stilyami semejnogo vospitaniya [Psychosomatic disorders in children in families with different styles of family education]. Povolzhskij pedagogicheskij vestnik - Volga Pedagogical Bulletin, 4(9), 121-126. Retrieved from https://cyberleninka.ru/article/n/psihosomaticheskie-rasstroystvau-detey-v-semyah-s-razlichnymi-stilyami-semeynogo-vospitaniya [in Russian].

9. Isaev, D.N. (1996). Psihosomaticheskaya medicina detskogo vozrasta [Psychosomatic medicine for children]. Saint Petersburg : Rech' [in Russian].

10. Krejsler, L. (1994). Psihosomatika v psihopatologii mladenchestva [Psychosomatics in the psychopathology of infancy]. Mat', ditya, klinicist: Sbornik-Mother, Child, Clinician: A Compilation, 112-145 [in Russian].

11. Miniyarov, V.M. (2006). Pedagogicheskaya psihologiya. Chast' I. Psihologiya vospitaniya [Pedagogical psychology, Part I. Parenting psychology]. Samara : Sam GPU [in Russian].

12. Mozgova, G.P., Khanetska, T.I., \& Yakymchuk, O.I. (2021). Psihosomatika: psihichne, tilesne, social'ne. Hrestomatiya: Navchalnyy posibnyk. [Psychosomatics: psycho, solid, social. Reader: Textbook]. Kyiv : NPU imeni M.P. Dragomanova [in Ukrainian].

13. Petryuk, P.T., \& Yakushchenko, I.A. (2003). Psihosomaticheskie rasstrojstva: voprosy definicii i klassifikacii [Psychosomatic disorders: questions of definition and classification]. Vestnik Associacii psihiatrov Ukrainy - Bulletin of the Association of Psychiatrists of Ukraine, 3-4, 133-140. Retrieved from http://www.psychiatry.org.ua/articles/paper144.htm [in Ukrainian].

14. Sandomirskij, M.E. (2007). Psihosomatika i telesnaya psihoterapiya: prakt. rukovodstvo [Psychosomatics and body psychotherapy: practical. leadership]. Moscow : Klass [in Russian].

15. Sel'e, G. (1992). Kogda stress ne prinosit gorya [When stress doesn't bring grief]. Moscow : MNPP "RENAR" [in Russian].

16. Starshenbaum, G.V. (2014). Psihosomatika: rukovodstvo po diagnostike i samopomoshchi [Psychosomatics: a guide to diagnosis and self-help]. Rostov-on-Don : Feniks [in Russian].

17. Shnejder, L.B. (2000). Psihologiya semejnyh otnoshenij. Kurs lekcij [Psychology of family relations. A course of lectures]. Moscow : Aprel'-Press; EKSMO-Press. Retrieved from http://psychlib.ru/mgppu/SPs/SPs-01.HTM [in Russian].

18. Ejdemiller, E.G., Dobryakov, I.V., \& Nikolskaya, I.M. (2003). Semejnyj diagnoz i semejnaya psihoterapiya [Family diagnosis and family psychotherapy]. Saint Petersburg : Rech' [in Russian].

19. Ejdemiller, E.G., \& YUstickis, V.V. (2008). Psihologiya i psihoterapiya sem'i [Family psychology and psychotherapy]. Saint Petersburg : Piter [in Russian].

20. Beketova, G., Mozgova, G., Shekera, O., Beketova, N., \& Liubava-Stephania (2019). Neurophysiological characteriscs of psychosomatic disorders and psychosomatic pathology in children and adolescents. Wiadomości Lekarskie is abstracted and indexed. Tom LXXII, 12(I), 2282-2288. Retrieved from https://wiadlek.pl/wp-content/uploads/2020/02/WL-12-cz-I2019.pdf

21. Dunbar, F. (1935). Emotions and bodily changes. American Journal of Psychiatry, 93(3), 749.

22. Dunbar, F. (1943). Psychosomatic diagnosis. New York-London : PB Hoeber. 


\title{
INFLUENCE OF THE FAMILY ON OCCURRENCE OF PSYCHOSOMATIC DISORDERS IN PRIMARY SCHOOL CHILDREN \\ Oksana Yakymchuk \\ PhD in Philosophy, Associate Professor \\ of the Department of Psychosomatics and Psychological Rehabilitation \\ National Pedagogical Dragomanov University \\ 9, Pyrohov Str., Kyiv, Ukraine, 01601 \\ Yakimchyk1409@gmail.com, https://orcid.org/0000-0002-9729-8389
}

\author{
Tetiana Khanetska \\ PhD in Psychology, Associate Professor, Associate Professor \\ of the Department of Psychosomatics and Psychological Rehabilitation \\ National Pedagogical Dragomanov University \\ 9, Pyrohov Str., Kyiv, Ukraine, 01601 \\ tanyadjan7@gmail.com, https://orcid.org/0000-0001-9767-5116
}

\begin{abstract}
The article emphasizes the importance of the problem of psychosomatic disorder growth in primary school-aged children. Medical sphere professionals are frequently confronted in their practice with the children, whose pathology puts them "in a dead end" as for the ways of dealing with it as it does not come with some visible changes in the somatic status. These are not manifested even in an indepth study, although accompanied by the changes in the child's psychological state. The impact of the family on the occurrence of psychosomatic disorders in children requires special attention to be studied while regardless of the family's well-being and general economic situation in the family, even with the favorable factors of child development, unconstructive style of family upbringing can trigger psychosomatic disorders. The psyche of the primary school-aged child is characterized with particular vulnerability and children's insufficient ability to think critically about the world that surrounds them. As a family member, the child gets into relationships with their parents who can have both positive and negative effect on them. Thus, harmonious relationships in the family, namely those of children with their parents, appear to be an essential condition for the mental development of a primary school-aged kid. Parents give children the sense of security, help them learn how to behave and respond to certain conditions in life. The results of the empirical study made it possible to identify the details of a family's influence on the occurrence of psychosomatic disorders in primary school-aged children. Moreover, they helped the authors figure out the level of parent's awareness of the tasks, content and methods of raising children; identify the peculiarities of parents' attitude, and determine the degree of children's satisfaction with their position in the family.
\end{abstract}

Keywords: psychosomatic disorders, primary school-aged children, style of family upbringing, psychological climate in the family, anxiety, stressful situations.

Подано 29.05.2021

Рекомендовано до друку 18.06.2021 